\title{
Currency Ratios and U.S. Underground Economic Activity
}

\author{
July 1998
}

\author{
Richard D. Porter and Gretchen C. Weinbach ${ }^{1}$ \\ Board of Governors of the Federal Reserve System \\ Division of Monetary Affairs \\ Mail Stop 72 \\ 20th and Constitution Ave., N.W. \\ Washington, DC 20551 \\ rporter@frb.gov (202) 452-2661 \\ gweinbach@frb.gov (202) 452-2841
}

\begin{abstract}
Cagan's classic currency ratio suggests that underground economic activity in the U.S. surged starting in 1994. In contrast, we show that a ratio adjusted to take care of two distorting developments -- retail sweep programs and overseas demand for U.S. currency -- did not surge, and that movements in the adjusted ratio are primarily due to the differential effects of interest rates on currency and checkable deposits. As a result, we are skeptical of monetary-based claims that the underground economy has expanded significantly in recent years and believe that any claims that it has must rely on other evidence.
\end{abstract}

Key words: currency ratios, underground economic activity, retail sweep programs, overseas U.S. currency (JEL classification: E69)

\footnotetext{
${ }^{1}$ The views express by the authors are theirs alone and do not necessarily reflect those of the staff or the Board of Governors. They wish to thank our colleagues Doug Elmendorf, Ruth Judson, Yvan Lengwiler, Chris Hanes, Jim Clouse, and Vincent Reinhart for incisive comments on earlier drafts.
} 
It is difficult to gauge the relative size of the underground or informal sector of the U.S. economy because transactions of participants engaged in tax evasion or other crimes are not readily observable. Police or court data could serve as indicators of the volume of overall illegal activity, but knowing the scope of those activities and the relative share of those which go undetected is problematic. Given the difficulties of direct inference, economists have often resorted to simple indirect methods of gauging underground activity. ${ }^{2}$ Since work by Cagan (1958), a convenient benchmark for underground activity in the United States and other countries has been the ratio of currency to checkable deposits. ${ }^{3}$ Because transactions in currency are anonymous while those involving checks leave an identifiable trace, participants in the underground sector have an incentive to use cash to hide the source of income from tax or police authorities. In this sense, a rise in the currency ratio, other things equal, could signify an increase in underground activity.

The standard currency ratio points to a dramatic pickup in U.S. underground activity over the past decade. Shown as the dashed line in Figure 1, the standard currency ratio was on a gradual upward path from 1965 until the end of 1993. Beginning in 1994, however, it has shot up, increasing more than 65 percent over the last four and a half years. From the perspective of

\footnotetext{
${ }^{2}$ National income accounts traditionally have attempted to measure legal underground activity but not illegal activity.

${ }^{3}$ Originally, the denominator in Cagan's currency ratio consisted only of demand deposits. However, this usage has become dubious in light of the growing popularity of interest-bearing NOW accounts in the 1970s and 1980 s in the U.S., which are identical to demand deposits in terms of their transaction properties. Thus, to update Cagan's approach to the present, both demand deposits and NOW accounts should be included in the denominator. More recent research using currency ratios includes Feige $(1997,1996)$ and Gutmann (1977). While one might be inclined to dismiss this literature for not accounting for all possible influences on the ratio, it does have the virtue of providing comprehensive estimates of underground activity. Because the conventional public finance literature is completely silent on this issue, these estimates are sometimes the best that are available for public policy purposes, for example, in allocating resources to combat money laundering.
} 
the currency ratio literature, this surge could represent an explosion in underground activity.

To pinpoint the basis for this surge, Figure 2 displays the components of the ratio: the time series of outstanding banknotes (currency in circulation excluding coins, the solid line) and checkable deposits (the sum of demand deposits and "other checkable deposits," which consists mainly of NOW accounts, the dotted line) in the United States. While banknotes have grown relatively steadily, checkable deposits, after spurting in the early and mid-1980s after NOW accounts were introduced, have recently declined very dramatically. This abrupt runoff of checkable deposits is mostly responsible for the recent surge in the standard currency ratio. However, this measure of the currency ratio does not take into account the effects of two important aboveground influences: retail sweep programs and currency held abroad.

\section{$\underline{\text { Retail Sweeps }}$}

A variety of innovations, enhanced computing power, the falling costs of computing, as well as the availability of easy-to-use software, apparently made it feasible beginning in 1994 for some banks to offer retail sweep programs that were consistent with Federal Reserve regulations governing various deposit accounts. By sweeping deposits, banks may profitably reduce the level of deposits subject to reserve requirements. They achieve this reduction by transferring checkable deposits, which are subject to a reserve requirement tax, to money market deposit accounts (MMDAs), which are not reservable. ${ }^{4}$ The dotted line in Figure 3 shows that through

\footnotetext{
${ }^{4}$ Banks administer sweep programs as follows. At the start of each month (or statement cycle), checkable balances above some target level are electronically transferred to a special-purpose MMDA. All activity in the account is applied directly to the checkable balance. If at the end of a day account activity has caused the balance to fall below the target level, banks electronically transfer funds back from the MMDA in order to restore the level of checkable balances to the target level. Regulations permit up to six transfers per month from an MMDA, so if account activity warrants a sixth such transfer, all remaining funds are swept back into the checking account. If, on the other hand, a customer's checking balance is greater than the target level at the end of a day, the amount in
} 
May of this year, sweeps had depressed the level of checkable deposits by more than $\$ 275$

billion, as measured by the sum of amounts initially swept as new programs were set up. ${ }^{5}$

\section{Foreign Currency Demand}

U.S. banknotes have been the preferred international banknote medium for some time.

The U.S. dollar serves as a medium of exchange and as a store of value when the purchasing

power of a domestic currency is uncertain or when other domestic assets lack sufficient

anonymity, portability, divisibility, liquidity, or security. Recently, though, crisis and instability

in several large and comparatively wealthy economies in Latin American and Eastern Europe

have created a surge in the external demands for U.S. currency. Obviously, overseas demands

for currency do not reflect domestic activity, and so a currency ratio that does not take into

account this distortion would incorrectly suggest that underground activity in the U.S. had picked

up. The solid line in Figure 3 shows one measure of currency held abroad, as estimated by the

Bureau of Economic Analysis (BEA) and the Federal Reserve; by this measure the cumulative amount of wholesale international shipments of U.S. dollars from 1965 through May of this year were nearly $\$ 210$ billion. $^{6}$

${ }^{4}$ (...continued)

excess of the target level is swept into the MMDA. See Edwards (1997).

${ }^{5}$ Depository institutions are not required to report amounts initially swept to the Federal Reserve when implementing new retail sweep programs. Nonetheless, some institutions are forthcoming with details of new sweep programs, and the majority of new sweeps are discovered in the course of routine editing of the daily deposits data that institutions do report. (Roughly 5,700 institutions currently report daily deposits data to the Federal Reserve for the purpose of calculating reserve requirements. These institutions account for almost 90 percent of all checkable deposits.)

${ }^{6}$ Cagan considered overseas currency in his analysis of the currency ratio in World War II but concluded that it had no significant impact. Feige (1996) also considered the matter more recently. The estimates discussed here differ from those in Feige as we use (newer) official estimates; see Bach (1997). These estimates represent net shipments of $\$ 100$ s from the New York and Los Angeles Federal Reserve branches as a proxy for all wholesale currency shipments. Porter and Judson (1996) show that $\$ 100$ s from the New York branch were the source of most 
Adjusting the standard currency ratio for both confounding factors, as in the solid line in

Figure 1, gives us a distinctly different series. ${ }^{7}$ While the unadjusted ratio is evidently

nonstationary, the adjusted ratio appears stationary and has only about one-fifth the range of

variation of the unadjusted series. This stationary behavior suggests that it is hard to point to the adjusted currency ratio for evidence of a pronounced upsurge in underground activity over this period. $^{8}$

In earlier work reviewing this subject, Porter and Bayer (1989) argued that most of the empirical literature that relied on monetary phenomena to tease out estimates of underground activity was flawed: The evidence marshaled to support estimates of a large and sometimes rapidly growing underground economy could largely be explained by economic activities of aboveground participants, including responses to interest rate movements. It turns out that

\section{${ }^{6}($...continued $)$}

of the net increase in overseas currency shipments. More recent work suggests an additional role for the LA branch as well, particularly in receiving currency shipments returning from overseas. The work indicates that the relative share of overall currency handled by the NY and LA branches is disproportionate to the population served by these branches, while at each of the other 35 branches the relationship is proportionate. See Porter and Judson (1996) for a general discussion of the methodological issues in estimating overseas currency holdings; also see Jefferson (1998) and Rogoff (1998).

${ }^{7}$ Data used to adjust the standard currency ratio are available through May 1998. To focus on longer-term issues, we use not seasonally adjusted, monthly-average series based on one observation per year (May). The currency series in the numerator is constructed as the average of the end-of-month figures for April and May, excluding coins (solid line in Figure 2), less the estimate for currency held abroad (solid line in Figure 3). The deposit series in the denominator is the sum of the May monthly averages of demand deposits and other checkable deposits (dotted line in Figure 2) plus the estimate of the cumulative amounts of new retail sweep programs (dotted line in figure 3 ).

${ }^{8}$ Other interpretations are possible. Survey evidence by Porter and Judson (1996) suggests that currency usage has gone down relative to checkable deposits from the mid 1980s to the mid 1990s. Some of this likely owes to the expanding use of debit cards and convenience use of credit cards. In addition, as the nominal scale of transactions in the economy rises with growth in nominal income but the denominations in which currency are issued remain fixed, checking accounts become relatively more efficient in carrying out large-scale transactions. In such circumstances, a flat ratio might reflect the combination of growing underground currency usage but shrinking aboveground usage. However, it should be noted that Porter and Judson also show that in per capita terms it is problematic for conventional estimates of criminal activity to explain a very large part of the currency held inside the U.S. 
interest rate movements resolve much of the variation in the adjusted currency ratio. Figure 4

shows that the adjusted ratio series is highly correlated with the interest rate on the five-year

Treasury bond. ${ }^{9}$ We can account for this by observing that most estimates place the interest-rate elasticity of currency to be significantly less than that of deposits. ${ }^{10}$ Thus, when interest rates were rising over the first part of the period until about 1980, deposit growth would have been more constrained than currency growth, leading to a rise in the adjusted ratio. Since then interest rates have drifted down, reaching levels not seen since 1965, and have almost elicited a complete reversal in the rise in the adjusted ratio.

While interest rates appear to explain the bulk of the movements in the ratio, some of the departures from the generally positive correlation of the adjusted currency ratio and the interest rate shown in Figure 4 are consistent with what one might have expected on the basis of a priori considerations. ${ }^{11}$ First, some gaps in the series may represent the degree to which data on retail sweeps and overseas currency holdings are inaccurately estimated -- that is, measurement error.

\footnotetext{
${ }^{9}$ The two series have a simple correlation of 0.798 based on 34 annual observations from May 1965 to May 1998 (the bond rate is the May monthly-average value to be commensurate with the monetary figures used here). See Lucas (1988) for theoretical and empirical justification for using longer-term rates as an opportunity cost measure. In any event, the comparable chart using the three-month Treasury-bill rate has a very similar appearance with a slightly-reduced correlation of 0.634 . This interest-rate interpretation was first given in Porter and Bayer (1989) though their results depend on specific money demand specifications while the ones presented here do not. Observe that the scale shown here for the adjusted currency ratio is different than that used in Figure 1.

${ }^{10}$ For empirical evidence supporting this point see Moore, Porter, and Small (1990). This divergence presumably arises because of the greater relative ease with which deposits can be re-allocated relative to that of banknotes, which are a considerably lumpier commodity as they are available in a limited number of fixed denominations. From a Baumol-Tobin perspective, relatively more of the currency transactors are at a corner solution in which they hold only currency, a circumstance that is relatively typical for those unable to afford a banking relationship.

"In his treatment, Cagan does not consider opportunity costs, as we have, but rather the own rate of return on deposits. Incorporating such a variable into a regression of the adjusted currency ratio on the five-year Treasury bond rate does not add to the goodness of fit. Indeed, the corrected $R^{2}$ falls as the own rate is added to the regression, and while the additional variable enters with the expected negative sign -- an increase in the own rate increases deposit demand, which lowers the ratio -- it is an insignificant explanatory variable (it has a t-ratio of - 0.4 compared with a t-ratio of 6.9 on the five-year Treasury bond rate).
} 
Moreover, we may have an economic explanation for two of the more important gaps. The most significant gap overlaps with the period of the so-called missing money during the 1970 s (Goldfeld, 1976), in which deposit growth (but not currency growth) was much less than what would have been expected from standard money demand models. Some of this phenomenon can be explained by the introduction of wholesale sweep programs in the 1970 s. ${ }^{12}$ While the gap continues beyond the missing money period, it occurs when inflation was generally accelerating but the tax code was not yet indexed for inflation. The confluence resulted in greater bracket creep in the tax code and may have induced more tax evasion that, in turn, required an increase in currency holdings. The other significant gap occurs at the end of the 1980s and the beginning of the 1990s. In this period actual and prospective failures of thrifts and banks may have raised some significant questions about the long-run viability of the banking system. In that environment, depositors might have been willing to hold extra amounts of currency relative to deposits because they perceived higher risks in holding deposits. ${ }^{13}$ The gap disappeared as bank profits began to soar, renewing confidence in the banking system.

In summary, while a standard ratio of currency to checkable deposits would suggest that underground activity in the United States has surged over the past decade, the adjusted currency to deposit ratio presented here, one that removes both the distortionary effects of new retail sweep programs and the overseas demand for currency, does not provide evidence of such a

\footnotetext{
12 The Federal Reserve has not routinely gathered information on the volume of wholesale sweeps (sweeps of checkable deposits held by generally larger businesses). Recent survey evidence suggests that wholesale demand deposit sweeps currently total at least $\$ 100$ billion. See the May 1998 Senior Financial Officer Survey, question 12.2 (http:/www.federalreserve.gov).

${ }^{13}$ An alternative explanation may lie in an underestimation of currency held abroad during the period since it coincides with economic crisis in Argentina, the collapse of communism, and the Gulf War.
} 
surge. Indeed, the movements in the adjusted currency ratio are primarily due to the differential effects of interest rates on currency and checkable deposits. As a result, we are skeptical of monetary-based claims that the underground economy has expanded significantly in recent years and believe that any claims that it has must rely on other evidence. 


\section{References}

Bach, C. L., 1997, U.S. International Transactions, Revised Estimates for 1974-96, Survey of Current Business, July, 43-55.

Cagan, P., 1958, The Demand for Currency Relative to the Total Money Supply, Journal of Political Economy, August, 303-328.

Edwards, C. L., 1997, Open Market Operations in the 1990s, Federal Reserve Bulletin, November, 859-874.

Feige, E. L., 1997, Revised Estimates of the Underground Economy: Implications of US Currency Held Abroad, in Underground Economy, edited by O. Lippert and M. Walker (Fraser Institute, Vancouver), 151-208.

, 1996, Overseas Holdings of US Currency and the Underground Economy, in Exploring the Underground Economy, edited by S. Pozo (Upjohn Institute for Employment Research, Kalamazoo, Michigan) 5-60.

Goldfeld, S., 1976, The Case of the Missing Money, Brookings Papers on Economics Activity, 683-730.

Gutmann, P. M., 1977, The Subterranean Economy, Financial Analysts Journal, 33, 24-27.

Jefferson, P. N., 1998, Seigniorage Payments for Use of the Dollar: 1977-1995, Economics Letters, 58, 225-230.

Lucas, R. E. Jr., 1988, Money Demand in the United States: A Quantitative Review, Carnegie Rochester Conference Series on Public Policy, Autumn, 29, 137-168.

Moore, G. R., R. D. Porter and D. H. Small, 1990, Modeling the Disaggregated Demands for M2 and M1 in the 1980's: The U.S. Experience, in Financial Sectors in Open Economies: Empirical Analysis and Policy Issues, edited by P. Hooper, et. al., Board of Governors, Washington, D.C., 21-105.

Porter, R. D. and A. Bayer, 1989, Monetary Approaches to Estimating Underground Economic Activity, in The Underground Economies: Tax evasion and Information Distortion, edited by E. Feige (Cambridge University Press, Cambridge), 129-157.

Porter, R. D. and R. A. Judson, 1996, The Location of U.S. Currency: How Much Is Abroad?, Federal Reserve Bulletin, October, 883-903.

Rogoff, K., 1998, Blessing or Curse? Foreign and Underground Demand for Euro Notes, Economic Policy: A European Forum, April, 263-303. 

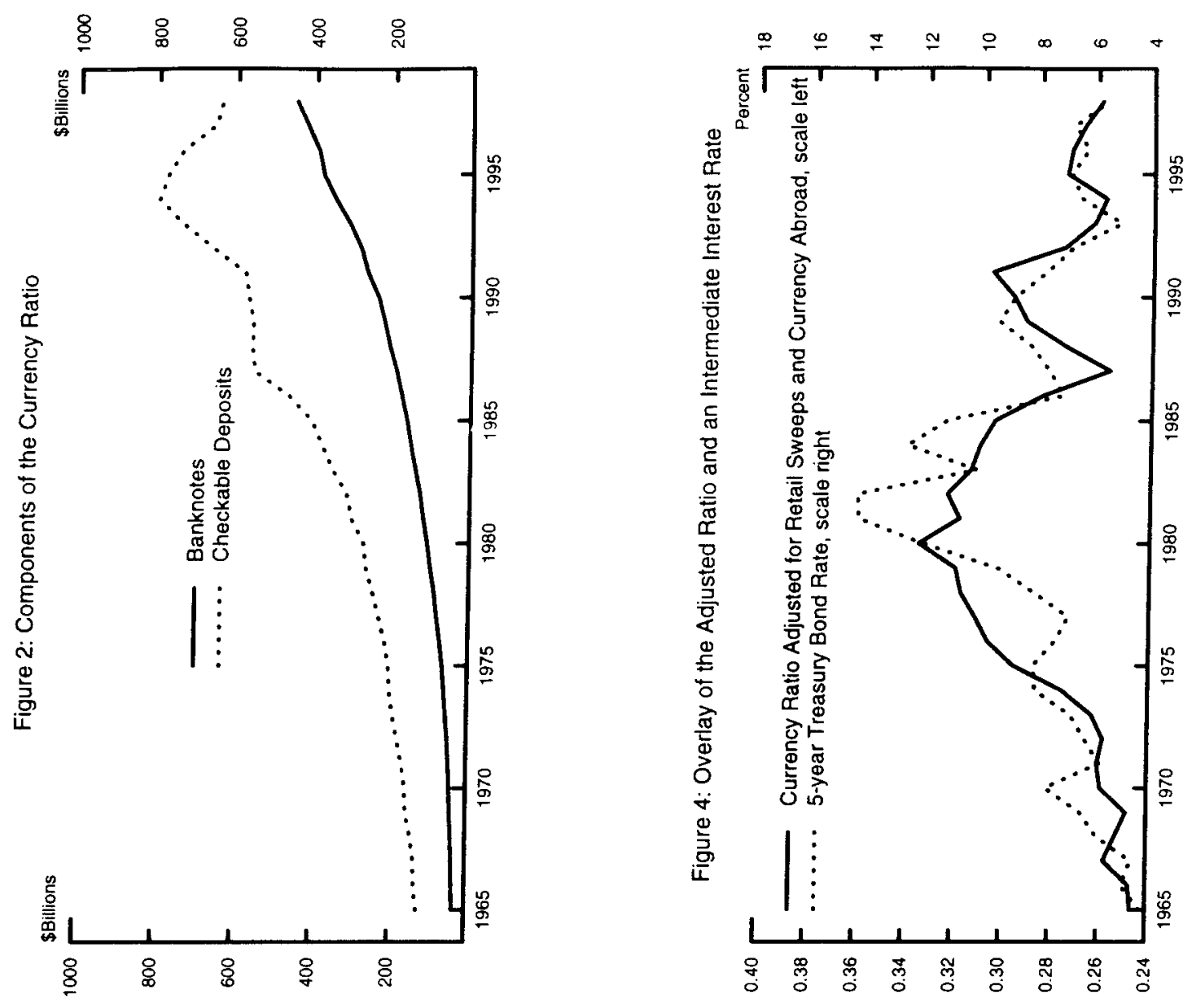

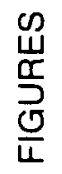
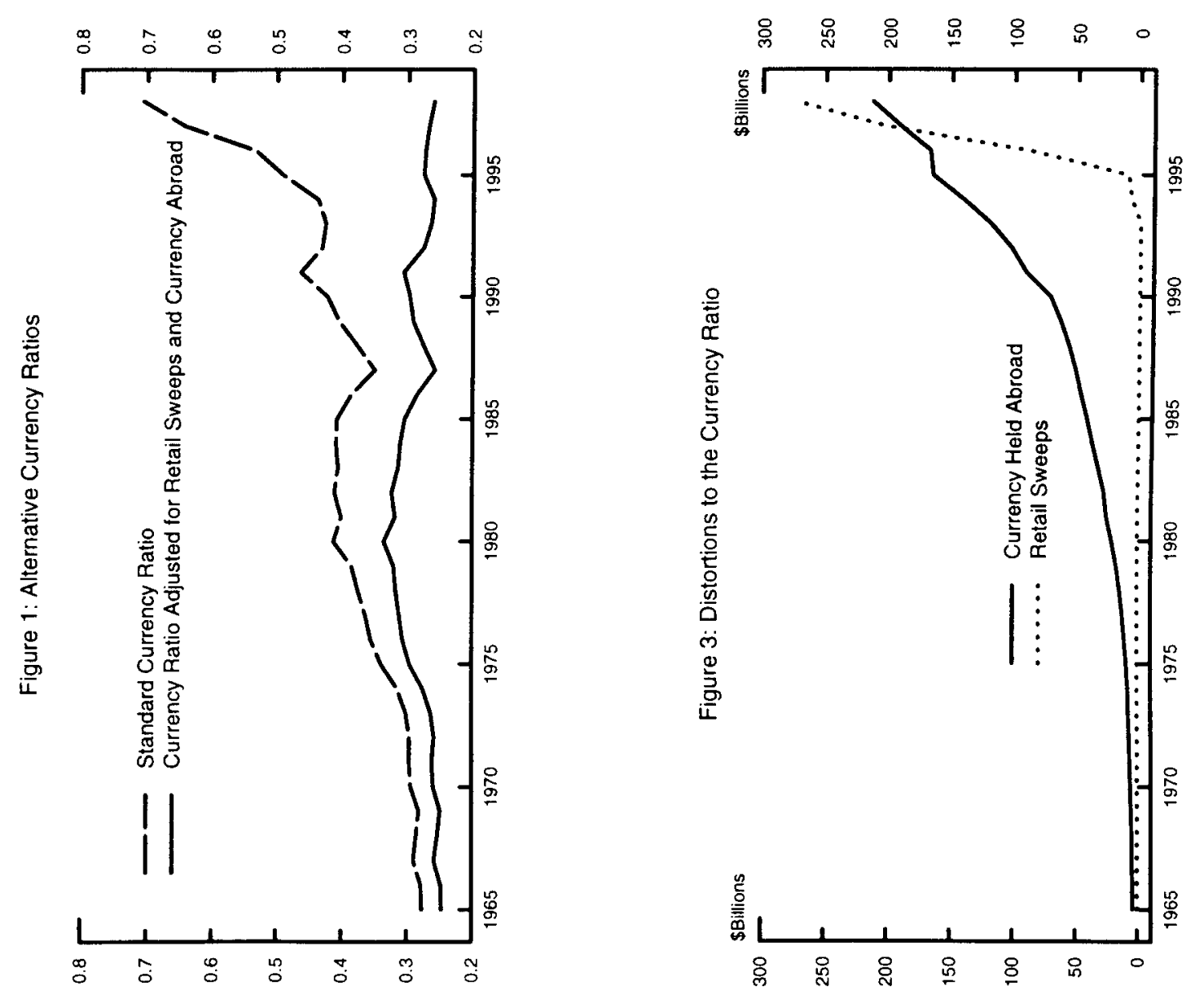